\title{
Research on the New Energy Vehicles Industry's National Development Strategy
}

\author{
Chao Peipei ${ }^{1}$, Gao Jinyan ${ }^{1}$, Yang Yang ${ }^{1}$, Hu Qingao ${ }^{1}$, Zhong Zhihua ${ }^{2}$ \\ 1. China Automotive Engineering Research Institute Co., Ltd., Chongqing 401122, China \\ 2. Chinese Academy of Engineering, Beijing 100088, China
}

\begin{abstract}
As an essential sector in the world's future automotive industry, new energy vehicles will introduce significant differences into China's energy, environmental, economic, science and technology, and societal development. In order to better support development decision making and ensure healthy and sustainable development of the industry, this research group has thoroughly studied the influences that the new energy vehicles industry will bring to China. We affirm that this industry has great strategic significance for energy security, emission reduction, environmental conservation, and industry transformation and upgrading for China. After providing a study of supportive policy and of the product technology level of the new energy vehicles industry (both domestic and overseas), and a summary and evaluation of the pros and cons of China's automotive industry, we offer proposals for strategic positioning, route selection, and cultivation priority for the future development of China's new energy vehicles industry.
\end{abstract}

Keywords: new energy vehicles; great significance; China-world comparison; strategic routes; key projects; policy proposal

\section{Introduction}

China's vehicle production volume has continued to grow during the 21st century, with China becoming the world's largest vehicle producer. Against this background, the vehicle industry's internal growth momentum, consumption structure, production mode, and competition pattern are undergoing profound changes, while energy, environment, industry, transportation, and other external factors are restricting the growth [1]. New energy vehicles are an important direction for the future development of the vehicle industry during the period of the 12th Five-Year Plan. The industry has made great progress and many achievements in production scale, technical and regulatory standards, and more; however, compared with the international level, a certain gap exists in core technological innovation, whole vehicle and battery safety, infrastructure, and so forth. During the period of the 13th Five-Year Plan, the industry faces intensified international competition and even bigger challenges for future development.

\section{The significance of the development of China's new energy vehicles}

As the focus of current and future global vehicle industry development, new energy vehicles will have great influence on energy, the environment, the economy, science and technology, and society in China. The development of new energy vehicles has followed the concept of circular economy development in China, and has also followed a cost-saving strategy. New energy vehicles have important strategic significance in promoting the transformation and upgrading of the vehicle industry, strengthening the industry's international competitiveness, and constructing an environmentally-friendly society [2].

\subsection{Reducing oil import dependency and ensuring national} energy security

In 2014, vehicle's oil consumption in China was about $2.5 \times 10^{8} \mathrm{t}$

Received: 5 August 2016; Revised: 15 August 2016

Author information: Chao Peipei, China Automotive Engineering Research Institute Co., Ltd., senior engineer. Her current research is in the development strategy of the Chinese energy-saving and new energy industry. E-mail: chaopeipei@caeri.com.cn

Funding program: CAE Major Advisory Project "Research on Promotion and Development Planning of China's Strategic Emerging Industries in the 13th Five-Year Plan Period" (No. 2014-ZD-7)

Chinese version: Strategic Study of CAE 2016, 18 (4): 069-075

Cited item: Chao Peipei et al. Research on the New Energy Vehicles Industry's National Development Strategy. Strategic Study of CAE, http://10.15302/J-SSCAE-2016.04.011 
- close to half of China's total oil consumption. At the same time, China's external oil dependency rose to $58 \%$. In future, if all Chinese cars continue to be made using traditional technology, oil consumption will reach $5.5 \times 10^{8}$ t by 2050 , which could result in a total oil consumption of about $8.5 \times 10^{8}$ t. At that point, China's oil import dependency would reach about $75 \%$, resulting in a serious challenge to our energy security, and especially to our oil security.

However, if the new energy vehicles are promoted on a large scale and account for about $60 \%$ of total car ownership, and if the number of cars in China increase to 350 million by 2050, then vehicles' fuel consumption will be about $2.5 \times 10^{8} \mathrm{t}-\mathrm{a}$ significant reduction in China's potential external oil dependency [3].

\subsection{Reducing pressure on greenhouse gas emissions and controlling atmospheric pollutant emissions}

If China reaches the goal of having new energy vehicles account for $60 \%$ of total car ownership by 2050 , it would see a reduction in $\mathrm{CO}_{2}$ equivalent greenhouse gas emissions of $5 \times 10^{8} \mathrm{t}$. Compared with the emissions from a continued use of traditional vehicle technology, this would amount to a $30 \%$ reduction in greenhouse gas emissions. Thus, the development of the new energy vehicles will help to effectively alleviate the pressure of greenhouse gas emission reductions [4].

Popularizing the new energy vehicles can result in reduced atmospheric pollutant emissions, so these vehicles have great significance toward improving urban air quality and ensuring human health. If polluting emissions from vehicles can be controlled due to new energy vehicle life cycle emission reductions, China will see remarkable benefits. If the market penetration rate of the new energy vehicles reaches $60 \%$ by 2050 , carbon monoxide (CO) emissions will be reduced by $2.7 \times 10^{6} \mathrm{t}$ and volatile organic compounds (VOC) emissions will be reduced by $6 \times 10^{5} \mathrm{t}-$ a reduction rate of about $60 \%-70 \%$. If the power ratio of clean energy such as solar and wind energy is greatly increased (i.e., $80 \%$ by 2050), then VOC and CO life cycle emission reduction rates will exceed $90 \%$ and those of nitrogen oxide and PM2.5 will exceed $80 \%$ [5].

\subsection{Transforming and upgrading the vehicle industry and even the manufacturing industry}

The development of new energy vehicles is the only way to transform China from a big nation into a powerful nation in the automotive industry. Electrification, intelligentization, and interconnection are the future development trends of the automotive industry, which is also a typical "internet-plus manufacturing" industry. The core of the new energy vehicles is the application of new energy driving power, the innovation and development of which not only include new technology in the vehicle motor, electronic control, and vehicle assembly sectors, but also highly integrate energy management, intelligent interconnection, and cloud service in a way that will greatly remodel the automotive industry. This will be both a challenge and an opportunity for our country, with its relatively weak industry base. If we grasp this opportunity, China may be able to transform from a big nation into a powerful nation in the automotive industry.

\subsection{Accelerating technological innovation in related industries}

As the typical new energy vehicle product is highly syncretic with the low-carbonization and intelligentization themes of the future, the new energy vehicles industry involves fields such as material science, information technology, control technology, manufacturing processes, and manufacturing equipment. The development of the new energy vehicles might effectively push technological innovation in basic research, design and exploitation, testing, and manufacturing in these related fields, and innovation in correlated technology and products may accelerate innovation in these fields.

\section{New energy vehicles: Development at home and abroad}

Ever since the 8th Five-Year Plan, after nearly 25 years of development, a relatively complete industrial system has been established for China's new energy vehicles. This system includes management policies, standards, and regulations that almost cover the industrial chain, from the top to the middle and lower steps. Since the 12th Five-Year Plan, science and technology research of special projects and project demonstrations are in synchronous implementation, allowing China's new energy vehicles industry to gain significant achievements in products, technology, and other aspects.

\subsection{Industry support policy}

Because the new energy vehicles industry is related to national energy security and the rise and fall of the vehicle industry, as the world's leading automotive manufacturing nation, China attaches great importance to the development of this industry. Many arrangements were proposed on a national strategic level, forming a complete set with a science and technology policy and an industrial policy [6]. The new energy vehicle support policy frameworks in the US, Japan, and Germany were originally born of energy and environmental policies; however, China's new energy vehicle support policies were born from science and technology innovation and industrial policies.

Because the new energy vehicles make up a new industry, the technical route for the top-level strategy design is not yet clear; most of the development planning is under constant adjustment. 
Since 2008, many developed countries have introduced specialized guiding policies for the development of the new energy vehicles industry; however, the perspectives of those policies are limited, with durations of only 10-20 years. Included in this planning is the development of American new energy vehicles through several stages of adjustment. At present, the main focus is on getting rid of heavy oil dependency and promoting industrialization. The global new energy development and the low-carbon economy originate in Europe, and the development of the electric car is an important part of the European Union's (EU's) green development strategy. Japan is developing new energy vehicles for the dual requirements of obtaining energy security and maintaining its industrial competitive advantage. South Korea's development stems from a desire to keep its position among the top four ranks of the vehicle industry, and to develop its new energy vehicles industry. In China, the development of "green" cars for society, including the creation of new jobs in order to establish the new energy vehicles industry, is almost in synchronization with the international development strategy, the strategic starting point of which includes corner overtaking, energy security, and environmental protection during the process of industry transformation and upgrading. However, China's longterm and big-picture framework is limited, and the technology roadmap requires further clarification.

The US government's support policy of the technical route for the new energy vehicles has been under adjustment. Support is mainly composed of setting up a fund to provide low-interest loans, project financing, and finance allocates, in order to support large enterprises to carry out project research and development. The current directions of technology input include electric technology, battery technology, and plug-in hybrid electric vehicle (PHEV) technology [7].

The EU has put forward a series of policies to encourage the development and application of renewable energies and biofuel. It has released the European Roadmap: Electrification of Road Transport as well as a budget and information system - the European research area communication network (ERA-NET) framework - to promote new energy technology research and development of the vehicle industry. The EU has invested 5 billion euros to support vehicle manufacturers in technology research and development [8]. Technical support for Japan's new energy vehicles industry follows a two-pronged premise: On the one hand, Japan pushes the research and production of new energy vehicles and their parts; on the other hand, it supports high energysaving vehicles and traditional hybrid vehicles, and achieves a different technical route choice in market competition. South Korea guides its vehicle industry investment using the production road map. It has specified eight main components that are in urgent need of research, provides direct financial support, and is developing a plan for new energy vehicle popularization. Chinese support is for pure electric and plug-in hybrid cars; policies have weakened regarding fuel cell vehicles and other alternative fuel cars, whose consistency and stability are insufficient. In addition, our country lacks a systematic policy design in new energy and transportation system integration for the new energy vehicles, renewable power, and the smart grid.

Industry development policy tools to support the new energy vehicles are relatively flexible in the US. At the federal level, the US provides fiscal subsidies, tax breaks, integral motivation through corporate average fuel economy (CAFE) standards, low-interest loans, government procurement, and so forth. At the local level, it provides tax breaks, high-occupancy vehicle (HOV) lanes, the zero-emission vehicle (ZEV) program, parking discounts, preferential charging price, car insurance discounts, and more [9]. In terms of new energy vehicle popularization, Japan always uses two policy tools that are mainly based on energy efficiency and emissions, while simultaneously providing a variety of tax cuts and fiscal subsidies. In addition, the US and Japan have comprehensive support policy systems on the new energy vehicles. Not only does the US provide a special fund for research and development, purchasing, and charging infrastructure, it also provides massive low-interest loans toward the construction of a productivity link. In recent years, the US has provided a total of 25 billion US dollars from the federal government in low-interest loans to manufacturers. China, however, mainly provides fiscal cash subsidies toward product sales, along with less effective use of fiscal investment and financing, preferential credit, direct investment, and other incentives. The industry preferential tax policy form is unitary, and is mainly dominated by direct preferential approaches such as tax reduction or exemption. It rarely uses indirect preferential forms such as accelerated depreciation and investment offset, and the tax system design cannot sufficiently reflect the industry guide, showing a lack of an effective combination of tax incentive and constraint mechanism. At present, China has not set up a green car tax system that is based on fuel consumption or emissions.

\subsection{The present state of vehicle technology development}

China's customized level of new energy vehicle technology is continually improving, and roughly implements the "three vertical and three horizontal" three big platform matrix system. The performance of the new energy bus has occupied a globally leading position, and China has exported buses to many countries including the UK and Brazil. Plug-in passenger cars commonly have a fuel consumption of less than $2 \mathrm{~L}$ per hundred kilometers; the driving range of an electric vehicle (EV) now exceeds $400 \mathrm{~km}$; technical indicators such as $0-100 \mathrm{~km} \cdot \mathrm{h}^{-1}$ sprint time and power consumption have been significantly elevated; the vehicle performance indexes for below-intermediate prototypes reach the international level. The fuel cell car is ready for preliminary prototype manufacturing. However, comparing developments in China with those abroad, a large gap exists in some key technologies (Table 1) [10]. 
Pure battery electric vehicles (BEVs) in China always share a platform with the traditional car, thus the module integration degree is too low to permit further optimization of the design. In contrast, BEVs abroad are often developed following the integration design concept, using a new platform; as a result, they have a higher level of vehicle design optimization and integration design. Regarding battery suppliers, most companies in China offer lithium iron phosphate batteries, which have high safety and a long life, but low energy density and a lack of lightweight technology. Enterprises abroad mostly use the manganese acid lithium battery and a ternary material battery, for its advantage in group technology.

For the PHEV, development in China is relatively consistent with development abroad regarding electromechanical coupling system configurations, and the composite group, parallel, and series-parallel configurations that are involved. A gap exists between development in China and abroad in the process of the industrialization of the hybrid system. Various hybrid systems have been implemented in large-scale sales abroad, especially the Toyota hybrid system (THS), which has accumulative total sales of more than 8 million sets. However, the cumulative sales for BYD's dual-mode all-wheel-drive hybrid system and for the SAIC intelligent electric drive unit (EDU) gearbox system are in the thousands, and other systems are all in the early stages of industrialization. In terms of the special hybrid engine, a significant gap exists between China and abroad. At present, only the Chongqing Changan Automobile Co., Ltd. and the Guangzhou Automobile Group Co., Ltd. have the related technology storage, although these have not entered the stage of commercialization. Gaps also exist between our country and abroad regarding torque-coordinated control technology, energy management technology, and regenerative braking technology.

Fuel cell vehicle (FCV) technology has developed rapidly abroad, and electric-electric hybrid technology solutions have become a focus in current development, with progress being made in product reliability and cost control. Fuel cell car powertrain technology platform research and development are almost simultaneous in China and abroad, using electric-electric hybrid dynamical system platform technology solutions. Domestic fuel cell producers have brought out an industrialized product, and the fuel cell industry has entered the stage of industrial demonstration and application.

Regarding the new energy bus, our electric bus is making progress in key technologies such as the electronically controlled air suspension chassis, wheel drive axle, reduced weight, electromagnetic compatibility, and so on; the product application is in a world-leading position. Both the product scale of the plug-in electric hybrid bus and its technical level have also made signif-

Table 1. Comparison of new energy passenger vehicle technology overseas and in China.

\begin{tabular}{|c|c|c|c|c|}
\hline Type & Comparing Index & US \& EU & Japan & China \\
\hline \multirow[t]{3}{*}{$\mathrm{BEV}$} & Platform & Newly developed & Newly developed & Share with traditional vehicle \\
\hline & Battery & LMO \& NCA & LMO and ternary & LFP and partly ternary \\
\hline & Motor & $\begin{array}{l}\text { Permanent magnet } \\
\text { synchronous motor or } \mathrm{AC} \\
\text { induction motor }\end{array}$ & $\begin{array}{l}\text { Permanent magnet } \\
\text { synchronous motor }\end{array}$ & Permanent magnet synchronous motor \\
\hline \multirow{5}{*}{ PHEV } & Way of coupling & $\begin{array}{l}\text { Torque coupling } \\
\text { Power coupling }\end{array}$ & $\begin{array}{l}\text { Torque coupling } \\
\text { Power coupling }\end{array}$ & $\begin{array}{l}\text { Torque coupling } \\
\text { Power coupling }\end{array}$ \\
\hline & System type & Serial parallel; in parallel & $\begin{array}{l}\text { In series-in parallel; Serial } \\
\text { parallel }\end{array}$ & Serial parallel; in parallel; in series \\
\hline & Oil conservation rat & $>40 \%$ & $>40 \%$ & $>40 \%$ \\
\hline & Product application & $\begin{array}{l}\text { BMW/ Mercedes/ } \\
\text { GM/VW }\end{array}$ & Honda/Toyota & Geely/BYD/SAIC \\
\hline & $\begin{array}{l}\text { Exclusive engine } \\
\text { technology }\end{array}$ & Yes & Yes & None \\
\hline \multirow[t]{3}{*}{$\mathrm{FCV}$} & Platform & \multicolumn{2}{|c|}{$\begin{array}{l}\text { Preliminary build of a new platform for vehicle } \\
\text { manufacturing }\end{array}$} & $\begin{array}{l}\text { Based on the traditional vehicle } \\
\text { modification }\end{array}$ \\
\hline & FCV engine & \multicolumn{2}{|c|}{$\begin{array}{l}\text { Mass power density: } 1600 \mathrm{~W} \cdot \mathrm{kg}^{-1} \\
\text { Volume power density: } 2700 \mathrm{~W} \cdot \mathrm{L}^{-1} \\
\text { Environmental suitability: }-30^{\circ} \mathrm{C} \\
\text { Service life of proton exchange membrane: } 7300 \mathrm{~h}\end{array}$} & $\begin{array}{l}\text { Volume power density: } 1300 \mathrm{~W} \cdot \mathrm{L}^{-1} \\
\text { Environmental suitability: }-10^{\circ} \mathrm{C} \\
\text { Service life of proton exchange } \\
\text { membrane: } 7300 \mathrm{~h}\end{array}$ \\
\hline & Auxiliary system of FC & \multicolumn{2}{|c|}{$\begin{array}{l}\text { Key technology breakthrough in compressor, humidifier, } \\
\text { hydrogen circulation device; has entered product testing and } \\
\text { industrialization stage }\end{array}$} & Basically none in China \\
\hline
\end{tabular}


icant progress. The pure electric driving range of typical products is over $65 \mathrm{~km}$, with a best fuel consumption of only $17.9 \mathrm{~L}$ per hundred kilometers. A breakthrough has been made in the chassis technology of the special plug-in electric hybrid bus. In addition, progress has been made in the technology of a full-load and dual-voltage composite energy storage system. This system was developed with completely independent intellectual property rights for many of its core technologies, with a double motor coaxial plug deep-mixing technology platform that includes a coaxial hybrid configuration, intelligent engine start-stop, a fivein-one controller, and a composite power supply.

\subsection{Current situation of the development of key parts}

With the rapid development of China's new energy vehicles industry, domestic three-electricity technology has undergone obvious improvement, the energy density of power battery monomers has continued to increase, motor performance is progressing steadily, and electric control is gradually achieving industrialization. However, compared with progress being made abroad, some key technologies and equipment technologies need further development (Table 2).

The main choice for the power battery of new energy vehicles being made abroad is a ternary system with a mixed manganese acid anode material. In contrast, the main choice for the power battery of new energy vehicles being made in China is the lithium iron phosphate battery, with a gradual shift to a ternary system currently occurring. Major countries involved in the indus- try, such as the United States and Japan, have made a layout in lithium battery basal core technology and in the industrialization of this technology ahead of time. However, at present, China does not possess innovative battery technology, but rather relies on imitating and following foreign technological development [11]. Regarding high-end products, the main developed countries have formed technical barriers with the key raw materials of power batteries, such as the positive and negative materials, the membrane, and the electrolyte. In China, however, the technology level is relatively low in aspects such as production equipment and system integration.

Regarding motors, China matches the international level in drive power density and efficiency, noise, vibration and harshness (NVH) performance, and more. However, China's manufacturing ability still requires improvement in terms of mass production technology and equipment.

Regarding electric control, the vehicle controllers produced abroad tend to be mature. Although there are small batches of domestic product entering the market, the controller hardware and development tools are dependent on imports, and a large gap still exists between Chinese and foreign product technology and industrialization ability. The core components of the motor controller in foreign products are mature, while domestic technology is still at the industrialization stage. A gap also exists between the Chinese and foreign levels of product integration, production technology, equipment, and reliability. For battery management systems (BMS), little difference exists between domestic and foreign versions, and Chinese technology has won market rec-

Table 2. Comparison of key component technologies of new energy vehicles.

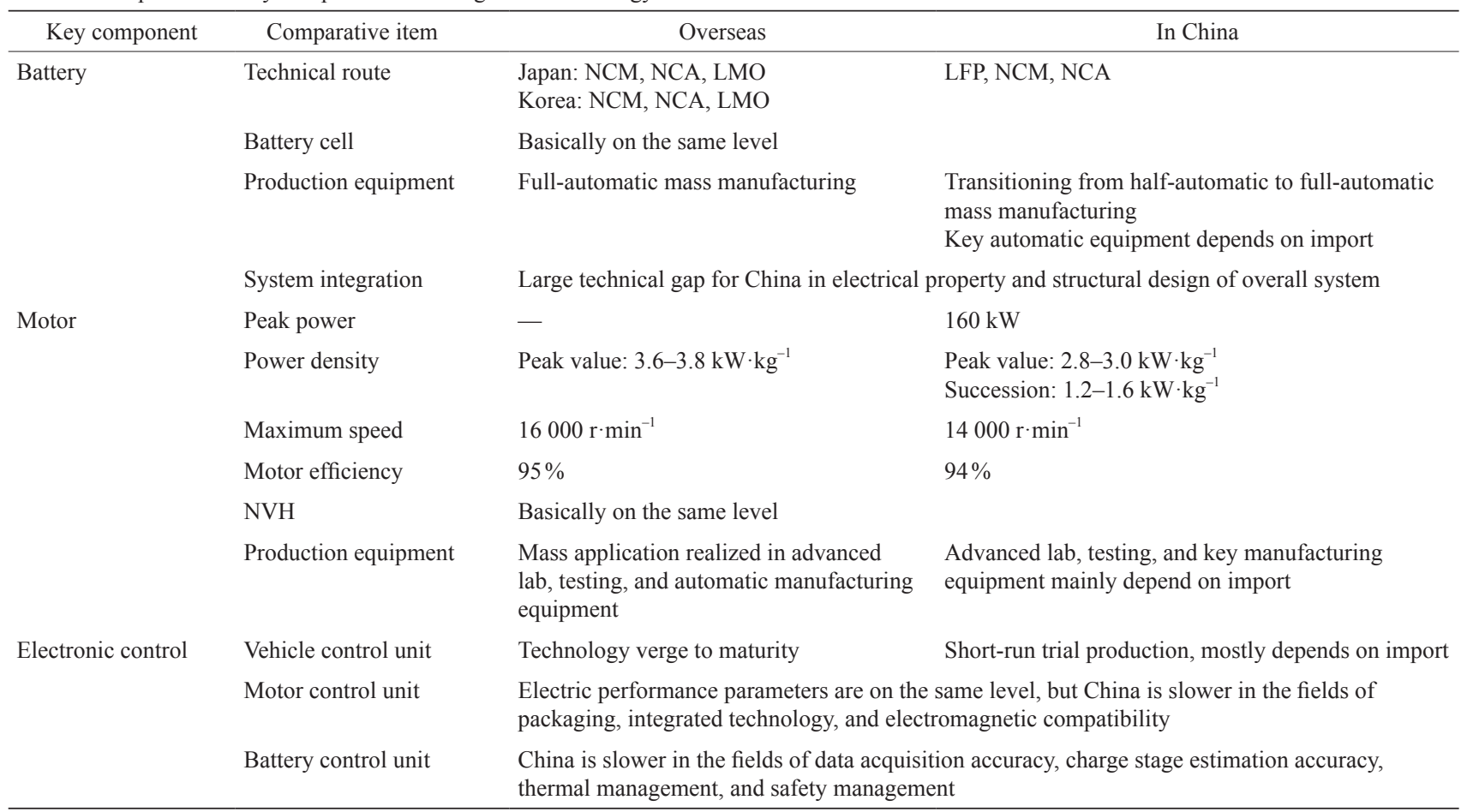


ognition. However, our state-of-charge (SOC) evaluation and theory model mainly imitate foreign technology, and parameter accuracy and dynamic control must be promoted.

\section{A strategic path for China's new energy vehicle development}

The original, worldwide goals behind the development of the new energy vehicles are energy security and environmental protection, with some countries also considering the cultivation of a competitive advantage in the vehicle industry. Faced with problems such as growing oil dependence, an increase in ecological environmental pressure, an extensive pattern of economic growth, and weak industry foundation, the development of the new energy vehicles industry in China is imperative. However, the starting point that is chosen will impact China's development path selection.

\subsection{Establishing reasonable overall strategic positioning}

China should establish a clear and strategic starting point that is based on energy, the environment, industrial competitiveness, and economic restructuring and adjustment. We should determine a medium- and long-term development strategy (up to 2035 or even 2050) with a wide perspective, within the national major strategic framework (i.e., of strategic emerging industries, energy strategy, ecological civilization and the urbanization construction, and the "One Belt One Road" initiative). Such a foundation will permit a clear definition of important development direction and development goals.

Compared with those in developed countries, China's vehicles industry started relatively late and its foundation is weak. However, the development of new energy vehicles provides a favorable opportunity for the corner overtaking of the current vehicles industry in China. Therefore, if we make it our core purpose to break through the barrier of core technology and promote the competitiveness of new energy vehicles industry, the development path of China's new energy vehicles industry should fully match the main development trend of the vehicles industry in the future.

\subsection{Establishing the route for key technology development}

From a long view, the overall effects of energy conservation and emission reduction coming from pure EVs and PHEVs will grow constantly as the proportion of new energy sources, such as wind, solar, nuclear, and biomass energy, continues to increase. Even if the current energy structure remains unchangeable, and the use of EVs and PHEVs only transfers the source of city pollution to the power station, the use of coal power can alleviate the pressure of China's dependency on foreign oil. In addition, in order to reduce oil consumption in the short-to-medium term and reduce the emission of atmospheric pollutants and greenhouse gases, we can encourage the development of traditional hybrid cars and alternative fuel vehicles over a certain period.

To this end, we should still follow the technical route put forward by the Energy-Saving and New Energy Vehicles Industry Development Plan (2012-2020) and the special plan for EV technology development set out in the 12th Five-Year Plan. We should continue to adhere to the "three vertical and three horizontal" research and development layout, and set pure electric power as our main strategic orientation. China should adapt to the overall technical transfer trend of the global vehicle electric power system and give play to our favorable conditions and comparative advantage. Regarding pure electric power, China should conduct strategies to transform the vehicle industry technology and speed up the development of pure electric power vehicle products. At the same time, we should pay close attention to the development of a new revolution in the science and technology environment, based on the integration of new energy vehicle technology, renewable energy, the smart grid, and new energy and transport system technology, such as intelligent transportation. China should encourage a technological cross and intergrating innovation that regards the $\mathrm{EV}$ as a core technology.

\subsection{Creating and cultivating the key industry chain}

China's present development trend of new energy vehicleslike the international development trend of new energy vehicles-combines the key components in the development of a new energy vehicles industry chain. These components include new materials, battery technology, the drive motor, the electric control system, vehicle enterprises, charging infrastructure and related intelligent energy, and intelligent cloud enterprises. In each part of the industry chain, we should identify one or two core enterprises to cultivate and encourage into a leading role in order to encourage industrial technological innovation and business model innovation.

In addition, China should realize an industrial integration that is centered on the electric car industry, such as the fusion of electric cars and the smart grid, the fusion of EVs and the intelligent transportation system, and the integration of electric cars and the mobile cloud. Not only will such integration give full play to the advantages of two industries, it will also provide new solutions to obstacles in the field.

\subsection{Propelling key projects forward}

The new energy vehicles industry will have an important role in and a large impact on China's economy and society. In addition, it will strengthen the national security strategy and increase China's competitiveness. Thus, we should focus on breakthroughs in core technologies, improve the current weak industry chain in application service systems, and put forward 
the following two major projects during the period of the 13th Five-Year Plan.

4.4.1. The new energy vehicle technology innovation project

- Project goal: To bring the overall technical level of China's new energy vehicles up to the advanced international level. This will involve a comprehensive breaking through of the technical barriers formed by foreign enterprises. New energy vehicle technology with independent intellectual property rights is widely used in domestic vehicle products, and its performance, price, reliability, and so forth can gain comprehensive recognition from consumers.

- The main components under development: We will develop power battery products, automobile motors, control systems and equipment, car networking technology, the electric chassis, a lightweight body, and vehicle integration development.

- Means: The project will involve special organizations, rolling projects year by year, as well as accelerating the product's entry into the market through the industrialization of the products on an acceptance basis.

4.4.2. The new energy vehicle application service engineering

- Project goal: To provide a complete and mature application service system for new energy vehicle market operations, and to realize perfect service at each service link, as consumers buy and use products, and require after-sale services. The economic benefit level of producers, infrastructure constructors and maintainers, and other investors is steadily rising, which will drive a significant rise in the industrial added value of the automotive aftermarket.

- The main components under development: We will develop a charge and exchange service system, a financial support system, an operating system, a customer service and maintenance system, a test evaluation and quality guarantee system, cascade utilization, and a recycling management system for the power battery.

- Means: The project will involve multivariate investment, franchising, high-quality safety responsibility systems in production enterprises, product spot-checking systems, and so forth.

\subsection{Enforcing the "dual-engine" driving force}

During the 13th Five-Year Plan period, China's economic development will enter a new normal, the key characteristic of which will be a tendency toward innovation-driven transformation. The market will play an important role in the allocation of resources. Therefore, the development of China's new energy vehicles should depend on a "dual-engine" approach. On the one hand, public services related to the new energy vehicle should be provided, including platforms for technology $R \& D$ and in- novation, market cultivation and promotion platforms, and the construction of charging infrastructure. On the other hand, the power and influence of the market should be appreciated. In order to serve public entrepreneurship and innovation regarding the new energy vehicles and encourage business model innovation, a tolerant policy environment should be provided.

\section{Policy suggestions for the development of China's new energy vehicles}

\subsection{Developing innovation investment and the financial leverage effect, and increasing investment in research and development}

Measures should include making full use of the guiding force of financial capital. Increasing incentives and investing accurately will improve the efficiency of funds. To explore funding, various financial resource elements, including banks, insurance, securities, and equity funds need to be to be leveraged to invest in science and technology innovation, creating a wide-ranging and fully integrated innovation ecosystem. It may be possible to set up a national vehicle industry innovation development fund, and guide social capital to increase investments in technological innovations regarding the vehicle industry. In addition, measures such as encouraging innovation in the organization patterns of R\&D institutes, supporting the well-known innovation alliance of new energy vehicles industry technology, and guiding coordinated development between innovation subjects can be taken into account.

\subsection{Providing centralized support to large-scale production,} and focusing on cultivating star products

Under the guidance of China's development path, enterprises producing complete vehicles and component parts, and having a certain scale of production and creative potential, should be identified. These enterprises can be encouraged to play leading roles and to establish and use cooperation among technology chains in the new energy vehicles industry, in order to cultivate a set of "star" product models. Moreover, the creation of a good policy environment for business model innovation (e.g., the $\mathrm{O} 2 \mathrm{O}$ fusion time-sharing leasing model) and appropriate applications are also necessary.

\subsection{Strengthening the formulation and implementation of the infrastructure construction-supporting policy}

Top-level design for the construction of the infrastructure for new energy vehicles should be improved. It should also be combined with new urbanization construction, smart grid construction, transport hub planning, regional economic planning, communication networks, housing construction and urban planning, 
urban fire-control systems, and so forth. Another measure that can be considered is increasing the construction of infrastructure for charging and replacing electric power, by making full use of existing energy nodes (i.e., point-line-plane connections) and providing the support to the State Grid, the China Southern Power Grid, and other traditional power supply enterprises. Other measures, such as establishing uniform standards and setting up an income-replacement rule to avoid facilities being idle due to non-conformant standards or division of profit, should be taken so that the utilization rate of the charging infrastructure can be improved.

\subsection{Diversifying the incentive policy of consumption}

The diversity of the incentive policy of consumption should be strengthened, and the guidance and effectiveness of the tax preferential policy should be improved. We can focus on stimulating consumption and implementing and innovating preferential models, in addition to widely implementing direct financial subsidies, tax relief, and methods such as low-interest loans, parking concessions, charging concessions, license concessions, insurance discounts, new energy integration management, and green taxation. In particular, the green tax system in developed countries can be used as a reference for adjusting the cost of the use of traditional vehicles in China with negative incentives, and reducing the cost of creating new energy vehicles. In addition, in order to increase consumer acceptance, increasing the cost performance of the new energy vehicles should be taken as the core of the policy design for the purchase of tax relief, and differentiated tax benefits should be given according to the different models, degrees of energy conservation and emission reductions.

\section{References}

[1] Ou X M, Zhang X L, Tan Y N. The group of manufacture power strategy research project. The comprehensive volume of manufacture power strategy research [M]. Beijing: Publishing House of Electronics Industry, 2015. Chinese.

[2] China Auto News Network. Exploring the resultant force of policy, promote energy-efficient and green car development coordination [EB/OL]. (2016-08-03) [2016-08-05]. http://www.cnautonews. com/jrtt/201608/t20160802_483095.htm.

[3] Ou X M, Zhang X L, Tan Y N. Life cycle analysis of electric vehicle charged by advanced technologies coal-power in future China [J]. Journal of China Coal Society, 2010, 35 (1): 169-172. Chinese.

[4] Ou X M, Zhang X L, Tan Y N. Analysis on future domestic EV energy consumption \& life cycle of green discharge [J]. Automobile and accessories, 2009 (13): 40-41. Chinese.

[5] Feng C, Xu Z Q. Study on the emissions of conventional air pollutants of long-term scale development of private electric vehicles [J]. Energy of China, 2016, 38 (5): 40-44. Chinese.

[6] Zhang Y W, Zhang J, Fang H F, et al. The assessment of new energy vehicles worldwide policies [M]. Beijing: China Machine Press, 2016. Chinese.

[7] Collantes G, Sperling D. The origin of California's zero emission vehicle mandate $[\mathrm{J}]$. Transportation Research Part A: Policy and Practice, 2008, 42 (10): 1302-1313.

[8] European Commission. Regulation(EU) No 333/2014 of the European Parliament and of the Council of 11 March 2014 amending Regulation (EC) No 443/2009 to define the modalities for reaching the 2020 target to reduce $\mathrm{CO}_{2}$ emissions from new passenger cars [R]. Europe, 2014.

[9] Energy and Environmental Economics. California transportation electrification assessment phase 2: Grid impacts [R]. California, 2014.

[10] Wang Z, Yuan Y. Analysis on the current technology situation and the development trend of new energy vehicles [J]. Technology and Enterprise, 2013 (16): 282. Chinese.

[11] Gallagher K G, Bauer C. Optimizing areal capacities through understanding the limitations of lithium-ion electrodes [J]. Journal of the Electrochemical Society, 2016, 163 (2): A138-A149. Chinese. 